розв'язання навчальних завдань, успішно контролюють процес їх виконання i відповідно оцінюють результати власної роботи. Мають сильну, усвідомлену та стійку мотивацію. Вони мають глибокі пізнавальні інтереси до кількох предметів, реалізуючи які, ці студенти систематично виходять за межі вишівської програми, їх захоплює сам процес навчання, пізнання. Престижний бік навчальної діяльності - на другому плані. Вони не виявляють надмірного занепокоєння 3 приводу оцінки їх успішності, якщо вона не відповідає сподіванням. 3 усіма труднощами, що виникають у процесі навчання, намагаються впоратися самостійно. 3-поміж інших студентів вони відрізняються високорозвиненою працьовитістю, тому для викладача $є$ опорою в роботі 3 групою; їх часто викликають відповідати тоді, коли інші не можуть (під час закріплення важкого навчального матеріалу, пригадування раніше пройденого).

Виявляючи старанність під час виконання всіх навчальних завдань, студенти цієї групи систематично й охоче допомагають іншим, є ініціаторами активного співробітництва 3 товаришами й викладачем у процесі навчання.

Творча активність виявляється через креативний рівень сформованості пізнавального інтересу, творчу самостійність, грунтовне знання програмного матеріалу, володіння елементами знань і навичок понад програму, здатність самостійно конструювати об'єктивно нову орієнтовну основу діяльності, у процесі виконання якої одержується об'єктивно нова інформація.

Висновки. Проведене дослідження не претендує на вичерпне розв’язання всіх аспектів проблеми, що розглядається. Виконана робота дозволяє окреслити перспективи подальшого розроблення питань щодо визначення критеріїв та рівнів пізнавальної активності студентів, щодо розроблення системних методів діагностування рівнів формування пізнавальної активності студентів.

\title{
Література
}

1. Горбач М. С. Психологічні умови керування розвитком пізнавальної діяльності / М. С. Горбач // Радянська школа. - 1980. -№7. - С. 22-27.

2. Китайгородская Г. А. Метод активизации возможностей личности и коллектива / Галина Александровна Китайгородская. - М. : МГУ, 2001. - 198 с.

3. Проблемы диагностики умственного развития учащихся: [учеб. пособ.] / под ред. 3. И. Калмыковой. - М. : Педагогика, 1975. - 206 с.

Стаття надійшла до редакції 27.05.2012 p.

УДК 371.134

A. С. Чумак,

кандидат пед.наук, ст. викладач, Криворізький педагогічний інститут ДВНЗ «Криворізький національний університет»

\section{ОРГАНІЗАЦІЯ ТВОРЧОЇ ДІЯЛЬНОСТІ НА УРОКАХ ТЕХНОЛОГІЙ ЯК ЗАСІБ ФОРМУВАННЯ КОМПЕТЕНТНОЇ ОСОБИСТОСТІ ШКОЛЯРІВ}

Чумак А.С. Організачія творчої діяльності на уроках технологій як засіб формування компетентної особистості иколярів.

У статті розкрито можливості організачії творчої діяльності на уроках технологій, спрямовані на формування певного комплексу компетенцій в учнів, які розкривають їхню здатність до професійної, творчої діяльності і життєдіяльності, що трунтується на знаннях, иінностях, досвіді, здібностях, набутих завдяки навчанню.

Ключові слова: творчість, урок технології, особистість. 
Чумак А. С. Организация творческой деятельности на уроках технологии как способ формирования компететнтной личности школьников.

В статье раскрываются возможности организации творческой деятельности на уроках технологии, направленные на формирование определенного комплекса компетенций у учащихся, которые раскрывают их способность к профессиональной, творческой деятельности и жизнедеятельности, основанной на знаниях, ценностях, опыте, способностях, приобретенных благодаря обучению.

Ключевые слова: творчество, урок технологии, личность.

Chumak A. The organization of creative activities in the classroom technology as a method of forming kompetetntnoy individual students.

In this paper the possibilities of creative activity in classroom technology, aimed at creating a set of skills in students who reveal their capacity for professional, creative activity and life, based on knowledge, values, experience, abilities acquired through training.

Key words: creativity, technology lesson, person.

Компетентність учителя технологій виявляється перш за все в естетичному сприйманні та перетворенні дійсності за законами краси, вмінні реалізувати творчі задуми у процесі створення чи реконструкції виробів. Більшість науковців переконані, що навчальна діяльність має дати учню не лише певну суму знань, але й сформувати комплекс компетенцій. Адже саме компетентність має стати тією метою навчання, досягнення якої прагне суспільство загалом.

Як стверджують науковці С. Гончаренко та П. Олійник, «компетенція це загальна здатність учня до професійної, творчої діяльності і життєдіяльності, що грунтується на знаннях, цінностях, досвіді, здібностях, набутих завдяки навчанню [4,c.23].

Особистісний розвиток людини відображає вікові та індивідуальні особливості, які необхідно враховувати в процесі виховання. 3 віком пов'язаний характер діяльності людини, особливості його мислення, коло його запитів, інтересів, а також соціальні вияви. Разом 3 тим кожному віку властиві свої можливості й обмеження в розвитку. Так, наприклад, розвиток розумових здібностей і пам'яті найбільш інтенсивно відбувається в дитячі та юнацькі роки. Якщо ж можливості цього періоду в розвитку мислення i пам'яті не будуть належною мірою використані, то в більш пізні роки вже важко, а іноді й неможливо надолужити згаяне. Водночас не можуть дати ефекту і спроби занадто забігати вперед у впливі на фізичний, розумовий i моральний розвиток дитини, без урахування його вікових можливостей.

Багато педагогів звертали увагу на необхідність глибокого вивчення $\mathrm{i}$ правильного врахування вікових та індивідуальних особливостей дітей у процесі виховання. Ці питання, зокрема, порушували Я. Коменський, Д. Локк, Ж. Ж. Руссо, а пізніше К. Ушинський, Л. Толстой та інші. Більш того, деякі 3 них розробляли педагогічну теорію, виходячи 3 ідеї природовідповідності виховання, тобто врахування природних особливостей вікового розвитку, хоч ця ідея інтерпретувалася ними по-різному. Я. А. Коменський, наприклад, у поняття природовідповідності вкладав думку про облік в процесі виховання тих закономірностей розвитку дитини, які притаманні природі людини, а саме: вродженого прагнення до знання, до праці, здатності до різнобічного розвитку тощо. Ж. Ж. Руссо, а потім Л. Толстой трактували це питання 
інакше. Вони виходили з того, що дитина від природи є істотою досконалою і що виховання не повинно порушувати цю природну досконалість, а йти за ним, виявляючи і розвиваючи кращі якості дітей. Проте всі вони сходилися в тому, що треба уважно вивчати дитину, знати іï особливості і спиратися на них у процесі виховання.

Науковими дослідженнями доведено, що існує пряма залежність між фізичним, розумовим і моральним розвитком людини. Фізичне виховання тісно пов'язане з удосконаленням органів чуття, зору, слуху, що, у свою чергу, має вплив на розумовий розвиток і формування характеру людини.

До найбільш яскравих особливостей народного декоративно-ужиткового мистецтва слід віднести надзвичайно влучні, продумані і правдиві характеристики конкретного образу, переданого у великій виразності форм, у яку вкладає народний майстер свій задум.

Все другорядне відкидається, поступаючись місцем головному, яке виявляється особливо чітко. Таке художнє трактування образу в народному мистецтві робить його особливо зрозумілим і доступним для сприйняття.

Іншою характерною особливістю творів народного декоративно-ужиткового мистецтва є барвистість і декоративність. Сміливі, часто контрастні кольорові сполучення відрізняють твори народного майстра, роблять їх привабливими.

Дослідник російського декоративно-ужиткового мистецтва М. Каменська підкреслює, що в декоративно-прикладному мистецтві народних майстрів чітко виокремлюються два види зображень - сюжетні та орнаментальні. 3поміж сюжетних зображень слід, перш за все, виокремили зображення тварин i птахів. Часто ці образи мали символічне значення. Лев, барс i орел символізували силу, владу, сокіл уособлював собою сміливість і відвагу, зображення молодої дівчини уособлювали весну тощо. Крім символічних образів, великого поширення набули й казкові образи: птах сирин, кентавр - напівлюдинанапівзвір, єдиноріг - кінь з рогом у лобі, крилатий звір - гриф тощо. Створені народною фантазією, вони зустрічаються в усіх видах народного мистецтва протягом багатьох століть. Маючи в основі образи живої природи, ці зображення, водночас, зберігали риси народної умовності [2].

Художня освіта i виховання засобами декоративно-ужиткового мистецтва спрямовані на розвиток в учнів високих естетичних ідеалів, формування потреб і здібностей до декоративного мистецтва у процесі духовного осмислення світу. Серед методичних принципів, адекватних специфіці мистецтва, художній образ є основою, на якій будується художньообразне сприймання мистецтва і власна творча діяльність учнів.

У психолого-педагогічній науці неодноразово наголошувалося, що нині, в умовах стрімко зростаючого обсягу інформації, особливого значення набуває розвиток i активізація творчих здібностей. Дійсно, будь-якій діяльності особливо важливим $є$ не просто засвоїти певну сукупність знань, а обрати найбільш значущі з них, зуміти застосувати їх під час виготовлення виробу.

Гнучкість розуму передбачає здатність до виокремлення істотних ознак з безлічі випадкових і здатність швидко перебудовуватися 3 однієї ідеї на 
іншу. Люди з гнучким розумом зазвичай пропонують відразу багато варіантів рішень, комбінуючи і варіюючи окремі елементи проблемної ситуації.

Систематичність і послідовність дозволяє людям керувати процесом творчості. Без них гнучкість може перетворитися на «стрибки ідей», коли рішення до кінця не продумуються. У цьому випадку людина, яка має багато ідей, не може зробити вибір. Вона не рішуча і залежить від оточуючих людей. Завдяки систематичності всі ідеї зводяться до певної системи і послідовно аналізуються. Дуже часто під час такого аналізу, на перший погляд, абсурдна ідея перетворюється і відкриває шлях до розв'язання проблеми.

Творчо мисляча людина також потребує здатності ризикувати і не боятися відповідальності за своє рішення. Г. Коджаспирова у своїх дослідженнях наголошує, що «це відбувається тому, що часто старі і звичні способи мислення зрозуміліші більшості людей» [3, с.56].

Будь-яку діяльність, зокрема і творчу, можна представити у вигляді виконання певних завдань.

Ефективність розвитку творчих здібностей багато в чому залежить від того матеріалу, на основі якого складені завдання. Аналіз навчальних посібників для школи показав, що творчі завдання, в основному, відносяться до «умовно творчих», продуктом яких є твори, виклад, малюнки, вироби тощо. Частина завдань спрямована на розвиток інтуїції учнів; знаходження кількох варіантів відповідей, творчих завдань, що вимагають усунення суперечностей, не пропонує жодна з використовуваних в школах програм.

Творчі завдання припускають використання у творчій діяльності школярів переважно методів, заснованих на інтуїтивних процедурах (таких як метод порівняння варіантів, морфологічний аналіз, аналогія тощо). Активно використовуються моделювання, ресурсний підхід, деякі прийоми фантазування. Так Ю. Бабанський у своїх дослідженнях наголошує, що «Програми не передбачають цілеспрямований розвиток творчих здатностей учнів за допомогою цих методів. Водночас для ефективного розвитку творчої діяльності школярів застосування евристичних методів має поєднуватися із застосуванням алгоритмічних методів творчості» [1, с.156].

На основі аналізу літератури можна виокремити такі вимоги до творчих завдань: відкритість (зміст проблемної ситуації або суперечності); відповідність умови обраних методів творчості; можливість різних способів розв'язання; урахування актуального рівня розвитку; урахування вікових особливостей учнів.

Відповідно до вимог можна побудувати систему творчих завдань, під якою розуміється впорядкована множина взаємопов'язаних творчих завдань, сконструйованих на основі ієрархічно побудованих методів творчості, зорієнтовану на пізнання, створення, перетворення і використання в новій якості об'єктів, ситуацій, явищ, спрямованих на розвиток творчих здібностей школярів у навчальному процесі.

Система творчих завдань містить цільовий, змістовний, діяльнісний і результативний компоненти. Системоутворювальний чинник - особистість учня: його здібності, потреби, мотиви, цілі та інші індивідуально-психологічні особливості, суб'єктивно-творчий досвід. 
Особливу увагу приділено творчій діяльності самого учня. Під змістом творчої діяльності розуміються дві його форми - зовнішня і внутрішня. Зовнішня - зміст освіти характеризується освітнім середовищем, внутрішня $\epsilon$ надбанням самої особи, створюється на основі особистого досвіду учня в результаті його діяльності.

Творча навчальна активність - це суб'єктивна сторона навчальної діяльності школяра, відображення потреб, інтересів, здібностей, вольових зусиль, емоційного ставлення. Системоутворювальний елемент творчої активності - мотиваційно-потребнісне ядро особистості учня.

Найважливіші умови формування творчої активності учнів - зміст матеріалу, що вивчається, характер діяльності. Формування творчої активності взаємопов'язане з розвитком самостійності.

Творча активність передбачає максимальне вираження індивідуальності. Основні компоненти творчої активності учнів: потреби, інтереси, схильності до творчої діяльності; перетворювальне ставлення до виучуваних предметів, об’єктів; готовність до перетворювальної діяльності; евристичний потенціал.

Розвиток творчої активності забезпечує накопичення системи знань, фонду розумових прийомів, операцій: операції мислення (що аналізує спостереження, порівняння, аналіз i синтез, абстракція, узагальнення i конкретизація); прийоми осмисленого запам'ятовування (смислове угрупування, складання плану, тез тощо); загальні способи навчальної роботи (вміння працювати з книгою, уміння слухати, спрйимати, планувати, контролювати); перенесення засвоєних знань, умінь і навичок на розв'язання нових завдань. Необхідно формувати інтуїтивні механізми, евристичний потенціал [4, с.37].

Творчі форми уроку залежно від характеру творчої діяльності поділяють на логічні й емоційно-образні (або емоційно-художні). До логічних форм належать уроки-лекції, семінари, практикуми, дослідження, захисту доповідей, рефератів. До емоційно-образних форм належать урок-концерт, композиція, монтаж, урок-новела, урок-казка, урок-уявна подорож. Підготовка і проведення емоційно-образних форм уроку багатобічно залучає учнів до творчості: добір схем або малюнку до виготовлення виробу, творчий підхід до виготовлення й оформлення вже виготовленого виробу - все це залишає у школярів відчуття співтворчості і сприяє перенесенню отриманих на уроках знань і навичок на творчу діяльність.

У своїх дослідженнях Я. Богдан наголошує, що «основною метою теми традиції декоративно-ужиткового мистецтва $\epsilon$ виховання працьовитості, старанної, творчої, з високою національною самосвідомістю особистості, готової сприйняти національні традиції свого народу» [4, с.64].

Охоплюючи широке коло навчальних і виховних моментів, уроки технологій, пробуджують естетичні почуття, розвивають естетичні смаки, стимулюють розвиток творчих здібностей школярів, активізують допитливість, кмітливість, сприяють трудовому вихованню учнів та професійному самовизначенню школярів.

У процесі навчання учні вчаться виконувати різні прийоми, навчаються виготовляти вироби різної складності. Вони оволодівають уміннями та 
навичками, які поступово вдосконалюються. 3 перших же занять необхідно стимулювати творчий підхід до виконання виробів.

Опанування учнями програми має забезпечити розв'язання таких завдань: виховання працьовитості, терпіння, старанності, вимогливості до якості роботи, вміння нести радість іншому; розвиток винахідливості, фантазії, творчих здібностей; формування потреби в трудовій діяльності; формування практичних умінь i навичок практичних дій; розширення світогляду на основі історичних подій, пов'язаних із давніми звичаями; виховання любові до праці, охайності, самостійності, наполегливості в досягненні мети, вміння працювати в колективі та самостійно.

Учні повинні знати: правила внутрішнього розпорядку та безпеки праці у шкільних майстернях, будову, призначення інструментів, передбачених програмою; правила роботи 3 інструментами та матеріалами; технологію виконання основних елементів; умовні позначення на схемах: послідовність виконання готових виробів; вимоги до підбору матеріалу; дотримуватися правил внутрішнього розпорядку та безпеки праці в шкільних майстернях; користуватися інструментами; добирати необхідний матеріал; виконувати основні елементи та поєднувати їх між собою для отримання готового виробу; складати творчий план технології послідовності виконання роботи, дотримуватися плану у практичному втіленні задуму; виготовляти та оздоблювати вироби, дотримуючись встановленої послідовності тощо.

Отже, практика реалізації програми дала змогу виробити деякі методичні рекомендації щодо організації творчої діяльності учнів на уроках технологій:

- перш ніж дати завдання на виконання певного виробу, вчитель має зробити його сам;

- на столах до кожного уроку має бути роздатковий матеріал 3 малюнком-прикладом та із супроводжувальним текстом. Це збереже час i пояснення вчителя будуть доступнішими;

- під час роботи над схемами та малюнками в зошитах учні повинні використовувати кальку чи копіювальний папір. Це дозволить зекономити час, а малюнок буде більш чітким;

- учитель на кожному уроці має працювати індивідуально 3 кожним учнем та групами;

- учителю необхідно проводити нетрадиційні уроки, застосовувати різні форми та методи роботи на уроці. Це сприятиме успішній організації творчої діяльності учнів на уроках технологій.

\section{Література}

1. Бабанский Ю. К. Оптимизация учебно-воспитательного процесса / Юрий Константинович Бабанский. - М. : Просвещение, 1982. - 512c.

2. Каменская М. О смысле художественной традиции. Критерии й суждения в искусствознании / М. Каменская. - М., 1965. - 219 с.

3. Коджаспирова Г. М. Педагогическая практика: [учеб. пособ. для уч-ся пед. училищ] / Галина Михайловна Коджаспирова.-М. : Издательство «Академия», 1998.-144 с.

4. Методика навчання і наукових досліджень у вищій школі: [навч. посіб.] / за ред.

С. У. Гончаренко, П. М. Олійника. - К. : Вища школа, 2003. - 323 с.

Стаття надійшла до редакції 30.05.2012 p. 